\title{
Attitude of Teacher Trainees towards Yoga as an Organised activity
}

\author{
Rajkumar B. Nanaware ${ }^{1}$ and Palanethra. $\mathrm{L}^{2}$ \\ ${ }^{1}$ Asst.Professor, R V Teachers College, Jayanagar II Block, \\ Bangalore, Karnataka, India - 560011 \\ ${ }^{2}$ Associate Professor, School of Research and Innovation, CMR University, \\ Bangalore, Karnataka, India - 560043
}

\begin{abstract}
Yoga is a healthy way of leading life,is now believed to be a form of science.The study aims at the identification of the level of awareness and attitude of teacher trainees towards the Yoga as an organised activity. To analyze it an attitude scale was administered. The reliability coefficient was 0.83 by Spearman brown. The statistical technique employed is mean, standard deviation and independent ${ }^{\prime} \mathrm{t}$ ' test. The level of significance was tested at 0.05 level. The findings of the study revealed that Arts and Science teacher trainees of the training colleges had sound awareness, Most of the arts and science teacher trainees' had favorable attitude towards Yoga,the variables of awareness and attitude were found to be positive and highly correlated.
\end{abstract}

Keywords: Organised Activity, Meditation, Attitude, Awareness, Yoga and All round development.

"We are guilty of many errors and many faults, but our worst crime is abandoning the children, neglecting the foundation of life. Many of the things we need can wait. The children cannot. Right now is the time his bones are being formed, his blood is being made and his senses are being developed to him we cannot answer "tomorrow". His name is "today". Gabriela mistral, 1948

\section{Introduction}

The all-round development of an individual is only possible through the development of organized activities in educational settings. Cocurricular activities are defined as the Organised activities that enable to supplement and complement the curricular or main syllabi activities at academic endeavor. For the holistic development of the child, there is an immense need for emotional, physical, spiritual and moral development. Co-curricular activities had proved its vital role in the development of the various domains of mind and personality such as intellectual, emotional, social and aesthetic development. Creativity, Enthusiasm and Energetic, Positive thinking are some of the facets of personality development and the outcomes of organized activities. These are the important half and parcel of academic establishments to develop the students' temperament furthermore to strengthen the schoolroom learning. Organized activities have a wide horizon to cater to the cultural, social, aesthetic development of the child.

Co-Curricular Activities facilitate in the development of various domains of mind and personality such as intellectual development, emotional development, social development, moral development and aesthetic development. Creativity, Enthusiasm, and Energetic, Positive thinking are some of the facets of personality development and the outcomes of Co Curricular Activities or Extracurricular Activities. Co-Curricular Activities are an essential part of the curriculum. These activities are important for the harmonious development of the personality. Earlier the activities like games, sports, excursions, picnics, singing, drawing, painting, etc. were not included in the curriculum and considered as Extracurricular activities. But now the importance of these activities is recognized by modern educationists. Therefore these activities are included in the total education program of school as well as college and turned as Co-Curricular Activities.

In this article you are going to understand about the concept of Curricular and Co-Curricular Activities, categorizing the Co-Curricular Activities and the importance of organizing CoCurricular Activities in educational institutions. As the term curriculum generally refers to the 
academic program of school and college in which the work is been done within the classroom, in contrast, the co-curriculum encompasses all activities that are held outside the regular curriculum. In some cases, in conjunction with the normal academic timetable of scheduled classes, the school as well as college to enable students to develop further all aspects of their character provided in these. The Co-Curriculum plays a vital role in providing a variety of options within the school and college environment so that all students can find educational pathways that match their individual preferences and abilities. Through participating in the Co-Curriculum, students shall be able to learn to live together and contribute to academic development and expand their interests and skills beyond the norm, giving them the course work opportunity to enrich their lives by experiencing activities which otherwise might have passed them by. A few examples of common educational opportunities that may be considered as an organised activity are Indoor and Outdoor Sports, NCC and NSS, Youth Parliaments, Student Associations, Yoga, Debates, Dance and drama, Art and Music and Literature clubs and buzz groups, etc.

\section{Review of Literature}

Good health is the right of every human being. But this right depends on individual, social and environmental factors. Along with environmental or social factors to an oversized extent, we can develop a better immune system and a better perception of oneself so that other conditions do not affect the North American nation adversely and that we can do physiological state. Health is a positive concept. Positive health doesn't mean simply freedom from malady; however, it additionally includes a jubilant and energetic feeling of well-being with a quantity of general resistance and capability to easily cultivate immunity against specific offending agents.

Yoga is one in every of the foremost powerful healthful system of treatment. It is having its thought of well-being that has been scientifically understood and bestowed by several.

Emerging society has considered physical fitness as one of the important indicators of health. Being physically fit has been defined as "the ability to carry out daily tasks with vigor and alertness, without undue fatigue and with ample energy to enjoy leisure-time pursuits and to meet unforeseen emergencies" (PCPFS, 1952). Physical fitness refers to the maximum capacity that people have or achieve while they perform physical activity that can be measured as the level of strength and flexibility of the muscular groups in different body parts. Further ventilator function is useful for the assessment of physical fitness in children.
Previous findings showed a positive relationship between physical fitness, during adolescence and arterial properties later in life (Twisk, Kemper, \& Mechelen, 2002) academic achievement (Chomitz et al., 2009) \& improved emotionality (Folkins, 1981). Recent study in India which has concluded that basic levels of healthrelated fitness are low among school children and reasons attributed to this trend were increasing affluence, and academic competitiveness, which forces the child to devote very little time to physical activity (Raja, Gupta, Bodhke, \& Girish, 2014). Yoga in its original form consists of a system of physical, psychological and ethical practices (Nagarathna \& Nagendra, 2001). The popularity of yoga is evident with emerging interest and research in therapeutic applications. Further, the estimated prevalence of practicing Yoga has increased in many countries (Barnes, PowellGriner, McFann \& Nahin, 2004; Siegel \& Barros, 2009). Earlier studies have shown positive effects of Yoga training in enhance minimum muscular fitness (Gharote, 1976), skeletal muscle strength and endurance of students (Mandanmohan, Jatiya, Udupa \& Bhavanani, 2003). Further, 2 recent study has shown yoga training improves lung function, increases the vital capacity, timed vital capacity, maximum voluntary ventilation, breath-holding time and maximal inspiratory and expiratory pressures (Vedala, Mane \& Paul, 2014). Furthermore, recent literature suggests that yoga improves children's physical and mental well-being (Hagen \& Nayar, 2014).

Yoga can be adopted as a lifestyle for promoting our physical and mental health. Yoga, if introduced at the college level, would help to inculcate healthy habits and lifestyle to achieve good health. The aim of yoga thus, at the school level, is to encourage a positive and healthy lifestyle for the physical, mental and emotional health of children. Yoga helps within the development of strength, stamina, endurance and high energy at the physical level. It also empowers oneself with increased concentration, calm, peace, and contentment at a mental level leading to inner and outer harmony.

The streams of Yoga The human personality can be divided broadly into four fundamental categories: emotional, active, intuitive and volitional. Patañjali has clearly understood this fact that each person has a different temperament and inclinations according to the predominance of one or more of these categories. He, therefore, knew that the yogic path had to be designed to suit the specific characteristics of an individual. Therefore, he suggests: Bhakti Yoga for those who are emotionally and devotionally inclined (refer to $1: 23 ; 2: 1 ; 2: 23,2: 45$; etc.). Jñāna Yoga for those who are intuitive by nature. He recommends reflection and inquiry into the real meaning of 
AUM (1:27-29) and also explains much of Samkhya philosophy $(2: 20,21$, etc. $)$ as a means to higher realization. He also makes it clear that all mental knowledge is limited. Rāja Yoga or Pătañjala Yoga for those with strong willpower; this is the theme of the entire scripture. Karma Yoga for those who are active by nature, though is not particularly mentioned, but certainly it is implicit in many Sütras. For example, the yamas and niyamas signify the karma Yoga in daily actions and duties. Karma Yoga is also implicit in the verses on bhakti Yoga. Patañjali knew that success in Bhakti Yoga leads automatically to success in Rāja Yoga; Jñāna Yoga leads to perfection of Rāja Yoga, and so forth. He knew that a person on the path of Yoga must integrate his whole being. Petty-mindedness and egoism have to be removed by any available method. All negative and limiting functions of the mind have to be erased. The stopping of the vrttis (mental modifications) can be achieved by vairāgya (detachment) and abhyāsa (practice of Yoga). (1:12) This statement includes all paths and techniques of Yoga. None are excluded. They all lead to success in Yoga.

\subsection{History and Origin of Yoga}

Yoga has its origin thousands of years past in Bharat. It has originated from a universal want to attaining happiness and obtaining eliminate sufferings. According to yogic lore, Shiva is considered the founder of yoga. Several seals and fossil remains of Indus Valley Civilisation, dating back to $2700 \mathrm{BC}$ indicates that yoga was prevalent in ancient India. However, systematic reference of yoga is found in Patanjali's Yoga Darshana. Maharishi Patanjali systematized the yogic practices. After Patanjali, many sages/yogis contributed to its development and as a result, yoga has now spread all over the world. In this sequence, on 11 December 2014, the United Nations General Assembly (UNGA) with 193 members approved the proposal to celebrate 'June 21' as the 'International Day of Yoga'.

The term Yoga has its verbal root as Yuj in Sanskrit. Yuj means joining (Yujyate anena iti Yogah). Yoga is that which joins. What are the entities that are joined? In the traditional terminology, it is the joining of the individual self with the universal SELF. It is an expansion of the narrow constricted egoistic personality to an allpervasive, eternal and blissful state of REALITY. Pātañjala Yoga is one among the six systems of Indian philosophy known as Saḍdarśanas. One of the great Rishis (Seer), Patañjali, compiled the essential features and principles of Yoga (which were earlier interspersed in Yoga Upanișads) in the form of 'Sūtras' (aphorisms) and made a vital contribution to the field of Yoga, nearly 4000 years ago (as dated by some famous western historians). According to Patañjali, Yoga is a conscious process of gaining mastery over the mind field (The Citta). The scope of Yoga as portrayed in the Bhagavadgītā and Upanișads is far more comprehensive. As Swami Vivekananda puts it "It is a means of compressing one's evolution into a single life or a few months or even a few hours of one's bodily existence". In general, there is a growth process due to interactions with nature in all creation. But it may take thousands and millions of years for this natural growth; that is the long, instinctive way in animals. Manas, endowed with discrimination power, conscious thinking faculty, the intellect (Buddhi) and well-developed voluntary control systems, aspires to accelerate his growth. Yoga is a systematic conscious process which can compress the process of man's growth greatly. Sri Aurobindo emphasizes on all-round personality development; at the physical, mental, intellectual, emotional and spiritual levels. He means by Yoga a methodical effort towards self-perfection by the development of the potentialities latent in the individual. It is a process by which the limitations and imperfections can be washed away resulting in a Superhuman race. Thus, Yoga is a systematic process for accelerating the growth of an individual in his or her entirety. With this growth, one learns to live in higher states of consciousness. Key to this all-round personality development and growth is the culturing of mind.

\subsection{Yoga - an Organised activity}

The word 'yoga' comes from a Sanskrit word 'Yuga'which means 'union'. Traditionally, yoga is a method joining the individual self with the Divine and Universal Consciousness. Physical and mental exercises are designed to help and achieve this goal, also called self-transcendence or enlightenment. On the physical level, yoga postures, called Aasanas, are designed to tone, strengthen and align the body. These postures are performed to make the spine supple and healthy and to promote blood flow to all the organs, glands and tissues, keeping all the bodily systems healthy. On the mental level, yoga uses breathing techniques called Pranayama and meditation (dhyana) to quiet, clarify and discipline the mind. The science of Yoga imbibe itself the entire essence of the method of Life, including - Gyan Yoga or philosophy, Bhakti Yoga or path of devotional bliss, Karma Yoga or path of happy action, and Raja Yoga or path of mind control.

Yoga attitude refers to a range of mental sets people can have towards the benefits of yoga refers to the harmonious well-being of body, mind, and spirit in people. As yoga generally has the tactic of creating a dynamic body, enriching the mind, and elevating the spirit. Over the past three 
decades, the research material available based on yoga has convinced the researchers that most of our fundamental attitudes to life have their physical counterparts in the body.

Extrinsically perspective is one in every of the psychological factors that verify one's endeavor and pursuits in life. Also male and feminine differs probably in most of the psychological traits. Thus comparison and criticism of awareness and attitude carry enough scope to be analyzed. An attempt has been made in the present study to investigate the Attitude of Teacher Trainees towards the Yoga as an organized or co-curricular activity.

Therefore the researchers have planned a study which aims at the identification of the level of awareness and attitude of teacher trainees of B.Ed colleges about their understanding of organized activities and also to find out the relationship between the attitude and awareness of teacher trainees towards the Yoga.

It has been observed that the practice of Yoga attunes the body, mind, and energy to bring balance and harmony in our personality. The balanced development of body, mind, and consciousness enhances the positive feeling towards life. The blend of ancient technology of Yoga with the present education system will have added advantages because it sharpens the human tool called mind by controlling it, its practices inculcates disciplines and sound moral and ethical values in pupil and learning about certain principles of life. The practice of yoga will help students deal with uneven situations in life, conflicts, distractions, routine problems, disease, and disorders. It will surely prepare students to deal with stress, realities of life, psychological growth and overall personality development. The present education system devoid of yoga education will be a linear development of students and the intellectual development will be kept in priority. The other aspect of personality like emotional, physical and mental factors will be more or less left out. Thus, through yoga in education, there will be an increase in rationality, emotional structure and creative output of the students. Also, enhancing the physical activity in students will yield healthier outcomes.

\subsection{Need of yoga for positive health:}

The fast-paced and competition-oriented modern lifestyle tends to overtax the psychosomatic homeostasis of human organisms, resulting in stress-related disorders, coupled with erosion of the age-old humane values. This has rendered the modern man sorely prone to psychosomatic disorders like Diabetes and Hypertension, amidst overwhelming environmental demands, whereby he has to play ever-changing roles to get going in a work-a-day life. Modern therapeutic interventions, based on reductionist principles of modern physiology, have proved to be largely ineffective, particularly in the case of psychic and psychosomatic disorders. Modern interventions, at best, can give only a symptomatic relief from such disorders. Though, these methods work on anatomic-physiological level, yet the cure eludes these therapeutic measures because these methods are not possibly equipped to treat the very substrate of the psycho-physiological phenomenon. Inarguably, man is a complex psycho-neuroimmuno-endocrinological phenomenon and, therefore, needs only a holistic approach towards solving his existential problems. Traditional therapeutic interventions, being through and through natively holistic, may hold the key in such a scenario. Yoga, a time tested and researchsupported practical science of the ancient lore, warrants a serious attention in the present context indeed! Yogic neurophysiology of Traditional Yoga--with its principles of Prāna (the prime energy dynamics operating within the body, creating the psycho-physiological substrate), as well as, with its subtle experience-awarenesstranscendence phenomenon--seems to hold a great promise for the modern man, thanks to the textual claims which have been, amply, supported by empirical research into Yoga practices. The healthrelated significance of Yoga has been perceived by Swami Kuvalayānanda, as early as in 1924: “.... The physical side is only a minor aspect of Yoga which is chiefly mental and spiritual." Yoga has always held a holistic view of Health, encompassing the mind-body-spirit complex, if we have a cursory glance at Yoga Darśana and Yoga practices, be it related to Pātañjala Yoga or Hațha Yoga. Ayyurveda too emphasizes the mind-body interdependence: "a particular type of body goes with a particular type of mind and, conversely, a particular type of mind with a particular type of body (Caraka Samhitā IV: 36)".

\subsection{Misconceptions about yoga :}

A person appeared on a spacious dais with a long rope in his hand. Drawing the attention of the curious audience he threw one end of the rope holding the other. The rope went swirling up and stood vertically quite unsupported in mid-air. The person using the vertical rope as a ladder climbed up effortlessly to reach the top and saluted the audience from his mid-air position. This rope trick cannot be called as Yoga. A long-haired halfnaked person was seen ready to enter a pit which measured 2’1’1 meters and had been dug specially for the demonstration. He entered into it and then the top of the pit is covered, so that no air could pass in it. The man remained inside for several days. He emerged out of the pit after a long stay, fresh and agile, with no symptoms of fatigue. This 
feat is called Bhūgata Samādhi. He is a great yogi, the common folk think. But he is not. The demonstration of Bhūgata Samādhi, Siddhis, magic, mantra-tantra etc. is what most people, even in India, associate with, when they hear the term YOGA. To summarize there are varieties of misconceptions associated with Yoga. Many persons who are laymen or not acquainted with the Indian culture and traditions think Yoga as associated with: ism

Religion - dogma, belief, cult or -

Magic, trick, mysticism

Physical culture - aerobics and

anaerobic

Mental concentration.

Self-mortification, self-torture etc

\section{Materials and Methods :}

Participants in the study are from the Teacher Training Institutes of Bangalore city, the standardized questionnaire was selected to administer. The 160 participants participated out of which 130 Girls and 30 Boys aged between 22-27 years approx. $(M=24.08, S D=4.52)$. The prior consent was obtained and permissions were taken from principal, data was collected personally on an individual basis. The information collected was tabulated and scored.

A comparative statement was prepared for analysis and interpreted by the investigator in terms of simple percentile analysis (t-test) along with mean and standard deviation. The statistical technique employed is mean, standard deviation and independent ' $t$ ' test.

For the collection of data, the researcher used Yoga Attitude Scale developed by Dr. M. K. Mucchal is used. The reliability coefficient was 0.83 by Spearman brown. The statistical technique employed is mean, standard deviation and independent ' $t$ ' test.

\subsection{Need for the study:}

Organised Activities develops skills for Life and Career of students. Co-Curricular and Extracurricular Activities offer a forum beyond the daily classroom experience for students to develop, practice and demonstrate new attitudes and skills and to work at becoming both independent and interdependent in a variety of different contexts. The most important benefit of yoga is physical and mental efficacy. So keeping in view the importance and benefits of yoga the researcher selected this study to know the attitude of secondary school students towards yoga.

\subsection{Objectives of the study:}

i To develop an understanding of yogic practices and apply in one's life and living. ii. To develop a healthy lifestyle in students.

iii. To inculcate values and morals in students.

iv. To develop sound physical, emotional and mental health through yogic practices.

v. To find out the attitude of teacher trainees towards yoga as an organized activity.

vi. To find out if there is any significant difference in the attitude of teacher trainees towards yoga based on their gender, academic stream and locality.

vii. To find out if there is any significant association of gender, academic stream, and locality with the development of attitude towards yoga as an organized activity.

\subsection{Sampling procedure:}

In the present endeavor, a random sampling technique was used and the questionnaire method was used to collect the data. The sample of present research comprises of 160 Teacher Trainees ranging age between 22-27 years approx comprising 130 Girls and 30 Boys.

\subsection{Hypotheses of the study:}

1. There is no significant difference in the attitude of teacher trainees towards yoga as an organized activity in relation to their gender.

2. There is no significant difference in the attitude of teacher trainees towards yoga as an organized activity in relation to their locality.

3. There is no significant difference in the attitude of teacher trainees towards yoga as a cocurricular activity in relation to the academic year of study.

4. There is no significant difference in the attitude of teacher trainees towards yoga as an organized activity in relation to their academic stream.(Arts, commerce or science)

Table 1: Mean attitude of students toward yoga of Entire sample and its sub sample.

\begin{tabular}{|c|c|c|c|c|c|c|}
\hline \multicolumn{2}{|c|}{ Variable } & $\mathrm{N}$ & Mean & $\mathrm{SD}$ & $\begin{array}{c}\text { 't' } \\
\text { value }\end{array}$ & $\begin{array}{c}\text { Level of } \\
\text { Significance } \\
\text { at } 0.05\end{array}$ \\
\hline \multicolumn{2}{|c|}{ Entire Sample } & 160 & 47.36 & 6.88 & & \\
\hline \multirow[b]{2}{*}{ Sex } & Boys & 30 & 46.16 & 6.86 & \multirow[b]{2}{*}{1.91} & \multirow[b]{2}{*}{$\begin{array}{c}\text { Not } \\
\text { Significant }\end{array}$} \\
\hline & Girls & 130 & 48.52 & 6.97 & & \\
\hline \multirow[b]{2}{*}{ Locality } & Rural & 34 & 48.11 & 6.93 & \multirow[b]{2}{*}{0.03} & \multirow[b]{2}{*}{ Significant } \\
\hline & Urban & 126 & 48.07 & 6.91 & & \\
\hline \multirow[b]{2}{*}{ Semester } & First & 78 & 45.46 & 6.74 & \multirow[b]{2}{*}{0.22} & \multirow[b]{2}{*}{$\begin{array}{c}\text { Not } \\
\text { Significant }\end{array}$} \\
\hline & Third & 82 & 47.71 & 6.90 & & \\
\hline \multirow[b]{2}{*}{ Stream } & Arts & 68 & 46.58 & 6.85 & \multirow[b]{2}{*}{0.30} & \multirow[b]{2}{*}{$\begin{array}{c}\text { Not } \\
\text { Significant }\end{array}$} \\
\hline & Science & 92 & 48.23 & 6.94 & & \\
\hline
\end{tabular}




\subsection{Delimitations of study:}

1. The researcher selected only 160 Teacher Trainees (B. Ed.) from Bangalore for the study.

2. The investigator selected only one Teacher Education Institute.

The researcher conducted study only on Arts, Commerce and Science Graduates

\section{$4 \quad$ Results and Discussions}

The obtained data were subjected to statistical analysis such as Mean, Standard Deviation and t-test to test the hypothesis. The analysis is presented and discussed below.

\section{Hypothesis 1}

There is no significant difference in the attitude of teacher trainees towards yoga as an organized activity in relation to their gender.

It indicates that the ' $t$ ' value $(-1.91)$ is not significant at 0.05 level. Hence, it can be inferred that there is no significant difference between boys and girls of B. Ed students in their attitude towards yoga

\section{Hypothesis-2}

There is no significant difference in the attitude of teacher trainees towards yoga as an organized activity in relation to their locality.

Table. 1 reveals that ' $t$ ' value $(0.03)$ is significant at 0.05 level. Hence, it can be inferred that there is no significant difference in the attitude of teacher trainees towards yoga as an organized activity in relation to their locality.

\section{Hypothesis 3}

There is no significant difference in the attitude of teacher trainees towards yoga as an organized activity in relation to their semester.

Table1 indicates that the ' $t$ ' value $(0.22)$ is significant at 0.05 level. Hence, it can be inferred that there is a significant difference between First and Third Semester Students.

\section{Hypothesis 4}

There is no significant difference in the attitude of teacher trainees towards yoga as an organized activity in relation to their academic stream. (Arts or science)

Table-1 indicates that the ' $t$ ' value $(0.30)$ is not significant at 0.05 level of confidence. Hence, it can be inferred that there is no significant difference between Arts and Science B. Ed students in their attitude towards Yoga.

\section{Conclusion:}

The present study revealed that there is no significant difference in attitude towards yoga between male and female teacher trainees. The average level of attitude towards yoga in male and female students was observed and recorded. The present study may help develop better understanding associated with the psychological background of yoga practitioners gender-wise.

Keeping in mind the findings and limitations of the present study, it may be concluded that male and female Teacher trainees carry almost the same attitude towards yoga also there is no significant difference in attitude in relation to their gender and Stream. The blend of yoga and modern education is the need of an hour and should be aimed at achieving good health, mental hygiene, emotional stability, moral values and making every student a responsible citizen of their country.

Yoga, being an ancient but perfect science, deals with the evolution of humanity. Yoga means union - the union of body with consciousness (mind) and consciousness with the soul.

It is a complete system or better a Science or a way of life. Yoga is a way of life can be applied irrespective of age, gender, profession, state, conditions, problems and introduction to Yoga and Yogic practices to every human endeavor will boost the holistic development of an individual personal, professional, social, family and societal.

\section{References}

[1] Asma Parveen and Umme Kulsum.(2017). Attitude of Secondary school students towards yoga. International Journal of Scintific Research. Volume 6, Issue2. Feb2017.

[2] Bhavanani, A.D. (2008). A Primer of Yoga Theory. Pondicherry: Dhivyananda Creations, Iyyangar Nagar.

[3] Bhogal, R.S. (2010). Yoga \& Mental Health \& Beyond. Lonavla: Kaivalyadhama SMYM Samiti,

[4] Bhogal, R.S. (2011). Yoga \& Modern Psychology. Lonavla: Kaivalyadhama SMYM Samiti. Bucher, Charles A. (1975). Foundation of Physical Education. St. Louis: The C.V. Mosby Co.

[5] Devi, I. (1987). Yoga, The Technique of Health and Happiness. Bombay: Jaico Publishing House.

[6] Digambar ji, Swamī \& Gharote, M.L. (1978). Gheraṇda Saṃhitā. Lonavala: Kaivalyadhama SMYM Samiti.

[7] Digambarji, Swamī \& Kokaje, R.S. (1971). Hațhapradīpikā. Lonavala: Kaivalyadhama SMYM Samiti. 
[8] Goel, A. (2007). Yoga Education, Philosophy and Practice. New Delhi: Deep and Deep Publications. http//www.wikipaedia.com

[9] John W. Best and James V. Kahn (1990). Research in Education. Seventh Edition

a. Prentice Hall of India Private Limited, New Delhi.

[10] Joshi K. S. (1984). Yogic Pranayama Breathing for long life and Good Health.
a. Udayana Publications, New Delhi.

[11]11. Kothari C.K. (1996). Research Methodology Methods of Techniques. Vishwa Prakashan, New Delhi.
[12]12. Nimavathi V. (2011). Attitude of B.Ed. Students towards Yoga. Edutracks, December.Neelkamal Publications PVT. LTD. Hyderabad.

[13]13. NCERT (2015) . Yoga - A healthy way of living. A text book for upper primary classes. First Edition. pp 312. New Delhi

[14]14. Patel, Ashimta.(2012). A Study of Attitude of B.Ed. Student- Teachers towards Yoga, Research Expo International Multidisciplinary Research Journal 2.2 (2012) : 213-216. 